\title{
Retraction Note to: High Heels Increase Women's Attractiveness
}

\section{Nicolas Guéguen ${ }^{1}$}

Published online: 11 October 2019

(c) Springer Science+Business Media, LLC, part of Springer Nature 2019

\section{Retraction Note to Arch Sex Behav (2015) 44:2227-2235 https://doi.org/10.1007/ s10508-014-0422-z}

The Editor-in-Chief has retracted this article (Guéguen, 2015) at the request of the Université de Bretagne-Sud. Following an institutional investigation, it was concluded that the article has serious methodological weaknesses and statistical errors. The data reported in this article are therefore unreliable. The author has not responded to any correspondence about this retraction.

\section{Reference}

Guéguen, N. (2015). High heels increase women's attractiveness. Archives of Sexual Behavior, 44, 2227-2235. https://doi.org/10.1007/ s10508-014-0422-z.

Publisher's Note Springer Nature remains neutral with regard to jurisdictional claims in published maps and institutional affiliations. 